\title{
Project-based Learning as a Tool for Student- Teachers' Professional Development: A Study in an Omani EFL Teacher Education Program
}

\author{
Saleh Al-Busaidi and Fawzia Al-Seyabi \\ Sultan Qaboos University, Muscat, Sultanate of Oman \\ https://orcid.org/0000-0002-9649-429X \\ https://orcid.org/0000-0002-1763-3467
}

\begin{abstract}
Project-based learning (PBL) helps students gain a deep understanding of the knowledge they acquire, develops higher levels of learning, and promotes the motivation to learn. Through self-inquiry, self-planning, and investigation, students learn to be independent thinkers and autonomous learners and pursue their learning needs by seeking solutions for real-life problems. The objective of this study was to explore the extent to which PBL approach helped 146 student-teachers at the College of Education, Sultan Qaboos University, Oman, develop their course design skills. The study utilized a questionnaire with multiple sections. The students were asked for their opinion about the approach, the difficulties they encountered, and suggestions for improvement. The results revealed that the students' responses were positive. The students enjoyed the project and agreed that it helped them gain many of the principles of courses design, as well as a host of academic skills. The students also reported a few challenges faced during the project such as needs analysis and writing goals and objectives. Teacher preparation programs in other contexts can benefit from the course design and the study findings to introduce change to their courses. Researchers and practitioners can also benefit from the challenges faced in implementing PBL in higher education institutions where one would expect students to be highly independent.
\end{abstract}

Keywords: English language teaching; Oman; project-based learning; teacher education program

\section{Introduction}

Universities and colleges around the world are expected to prepare a generation of students who are equipped with good communication skills, creative and critical thinking skills, and a mindset for problem solving and innovation in a world that is becoming increasingly complex and unpredictable (Roessingh \& Chambers, 2011). Although still dominant, the use of the lecture method in higher education institutions is far from adequate. in the last few decades there has been 
a shift to more open-ended approaches to teaching that value inquiry, reflection, problem-based learning, discussion and collaboration, and self-directed learning (Harmer \& Stokes, 2018; Holm, 2011; Bell, 2010). The literature on student learning revealed that learning by doing and experiencing is much more meaningful and permanent for the students than passive learning (Bell, 2010; Holst, 2003; Howard, 2002), and that this is one of the main constituents of contemporary education.

Project-based learning (PBL) can be defined as a student-centred teaching and learning model where students acquire content knowledge and skills through the design, development, and completion of projects (Vogler et al., 2018). PBL is one approach to education that emphasizes the learner and his/her role in the learning process. It allows students to control and have their own voice over their learning, which is an essential component of the learning process rather than teachers directing students' learning (Habók \& Nagy, 2016). PBL has been used in various educational contexts and levels starting with pre-school and primary education up to higher education levels including initial teacher preparation programs.

The PBL approach is an important tool to improve the synergy between theoretical and practical aspects of preservice teacher education (Nikolaeva, 2012). Several studies have reported the impact of the PBL approach on pre-service teacher training (Baran \& Maskan, 2010; Goldstein, 2016; Holst, 2003). Holst (2003) for example reports on how future English teachers in Singapore enjoyed the creative process of PBL and how they valued the opportunities for peer interaction. Other reported benefits of PBL in teacher preparation programs are the development of research, collaborative, speaking, and leadership skills. Researchers have also maintained that pre-service teachers' firsthand experience with PBL as learners will influence their own beliefs and practices as future teachers. They are more likely to transfer the skills they learnt to their own future classrooms (Holst, 2003; Howard, 2002).

PBL is not considered an extra or a supplementary material in the curriculum; it is a strategy for supporting learning and completing tasks (Bell, 2010). PBL is grounded on the basis of solving multiple problems with the provision of contextual and authentic experiences (Eskrootchi \& Oskrochi, 2010), which will ultimately enable students to scaffold their learning, and draw realistic connections between a specific context and later outcomes (Susanti et al., 2019).

The existence of authentic learning tasks in PBL is stressed and marked as an important feature (Eskrootchi \& Oskrochi, 2010; Holubova, 2008; Susanti et al., 2019). Through PBL, students are exposed to real and contextualized problemsolving environments and learning experiences that increase their skill, knowledge, and abilities. Since students investigate real-life problems and apply their knowledge in real contexts to solve a problem or create a product, they make meaningful connections between what they know and what actually happens in real life (Holubova, 2008). Therefore, learning is authentic as it relates directly to students' life and the outcomes reflect a real-life problem (Eskrootchi \& Oskrochi, 2010). This inclusion is also predicted to prepare students for higher education, which stresses what students are taught and what they actually do later in their jobs. Success in a job depends heavily on the interaction between knowledge that 
students developed through engagement in PBL during their studies and their application of this knowledge (Burlbaw et al., 2013). Bell (2010) points out that PBL is a student-centered and teacher-facilitated approach that allows students to seek knowledge by raising questions about contexts that interest them and attract their natural curiosity. Additionally, it requires teachers to be able to design high quality experiential learning activities. Once the learning goals are identified, the teacher designs expectations to complete the authentic task or the artifact (Holubova, 2008).

Projects are attractive to students and teachers because of their flexibility. They are designed according to diverse forms related to culture, development, cognition, and motivation. Students design their projects based on different standards such as their readiness to initiate them, their interest in designing them, and the project content and its processes. The flexibility it offers allow students to develop more skills as they proceed with working on their projects. They also foster collaboration, an important skill in the $21^{\text {st }}$ century workplace (Holubova, 2008; Bell, 2010).

Engaging students in PBL yields several effective outcomes on students' learning and life. Students gain a deeper understanding of a certain topic or a problem, deepen their learning to be highly familiar with and knowledgeable about the topic under investigation, develop higher level of reading and promote their motivation to learn. Students learn to be independent thinkers and autonomous learners who pursue their learning needs by seeking solutions for real-life problems (Bell, 2010; Habók \& Nagy 2016). Through self-inquiry, planning, research organization, and use of different learning strategies, students become equipped to solve real-life problems. As a result, students may feel empowered.

The features of PBL presented above were implemented in an educational course offered to Omani student teachers in the College of Education at Sultan Qaboos University as part of a teacher preparation program. The project required students to design a mini English course of their choice for a specific group of learners. The project was introduced in Educational Curriculum in 2016. Since then, it has not been evaluated as a new addition to the course. In this study we explored students' perceptions towards the project-based course-design approach. It specifically sought to answer two research questions:

1. What are the student teachers' perceptions about the PBL course design project?

2. What difficulties did the student teachers face during the PBL course design project?

\section{Literature Review}

\subsection{Theoretical basis of project-based learning}

The development of PBL has been underpinned by the cognitive learning theory, social learning theory (Thomas, 2000), and inquiry-based learning (Johnson and Cuevas, 2016), because PBL was developed based on the principles of these theories. It is believed that constructivism promotes deeper and meaningful learning as students engage in knowledge construction (Dolmans et al., 2005; Holubova, 2008). 
PBL has been linked with the principles of knowledge, thinking and doing. Researchers believe that previous experiences contribute to learning because they engage learners in real-life situations where they learn by doing. There is a strong tendency to incorporate the 21st century skills (problem-solving, communication and collaboration) in the learning process to help learners acquire knowledge, skills and competencies required in the real world (Baghoussi \& El Ouchdi, 2019). PBL enables learners to acquire and use these skills in and outside the classroom. (Baghoussi \& El Ouchdi, 2019; Burlbaw et al., 2013; Eskrootchi \& Oskrochi, 2010; Thomas, 2000).

Constructivism has become a crucial component of PBL due to its emphasis on learners' experiences (Mioduser \& Betzer, 2007). Some researchers (Baghoussi \& El Ouchdi, 2019; Bell, 2010; Burlbaw et al., 2013; Dolmans et al., 2005; Slough \& Milam, 2013; Thomas, 2000;) explained that students build on their existing knowledge when they are exposed to different experiences and problems. Students then connect the new knowledge to pre-existing knowledge to form a new schema. In the learning context, students acquire a new knowledge and build on a previous knowledge by analyzing it and connecting it with real-life contexts (Baghoussi \& El Ouchdi, 2019; Doppelt, 2005).

Habók and Nagy (2016) indicate that social constructivism emphasizes the importance of social interaction as a learning theory. The social environment is a crucial element for learning since it prepares social interactions with skilful others (Baghoussi \& El Ouchdi, 2019; Bell, 2010; Burlbaw et al., 2013; Dolmans et al., 2005; Habók \& Nagy, 2016; Thomas, 2000). This predicts that learners can construct new understanding through interaction with the environment (Demian, 2007; Dolmans et al., 2005; Panasan \& Nuangchalerm, 2010). Principles of social constructivism resemble those of the Zone of Proximal Development, also known as scaffolding, where learners are provided with the instructions and guidance needed to develop their skills to be able to use them later independently (Baghoussi \& El Ouchdi, 2019). It is an essential element for students' projects as it supports their self-confidence and the development of higher-order and critical thinking skills (Baghoussi \& El Ouchdi, 2019; Bell, 2010; Jollands et al., 2012), where less competent learners learn from more competent peers (Baghoussi \& El Ouchdi, 2019) through shared thinking and constructive feedback (Bell, 2010). In this context, learners have the opportunity to exercise higher-order thinking skills that develop their ability to inquire, plan, judge, scrutinize, make decisions, draw conclusions, and synthesize, which eventually enable them to evaluate their own projects (Baghoussi \& El Ouchdi, 2019).

PBL is also based on the principles of inquiry-based learning where students are required to discover and build new knowledge by engaging in activities and investigations that relate to their personal life (Panasan \& Nuangchalerm, 2010). Students drive their own learning, which is believed to increase their motivation to learn and improve critical thinking skills (Johnson \& Cuevas, 2016). 


\subsection{PBL criteria}

Thomas (2000) maintains that there are five main criteria to the application of PBL. These criteria include students' centrality, driving questions, constructive investigations, autonomy and realism. These criteria are established to identify aspects that a project must include in order to be called a "real project". Following these criteria, Boss and Krauss (2007) provide the following descriptions of PBL. First, projects are integrated in the curriculum and form an essential part of it; they are not supplementary materials, nor can they be deleted. Second, PBL allows learners to practice authentic strategies through engagement in real-life activities. Third, collaborative work helps learners solve real problems that interest them. Fourth, learners use technology as an assistive tool in their discoveries, collaboration, and communication. Teachers consider technology as a new strategy to reach learning goals. Fifth, teachers are requested to work collaboratively to design and apply projects that go beyond geographic boundaries and time zones.

\subsection{Studies examining PBL in learning/teaching in higher education}

There is a plethora of studies that investigated the efficacy of PBL as a learning and teaching tool in a wide range of disciplines and across different educational levels. In the context of language learning, studies found that PBL succeeded in the following aspects: richer engagement of students by working on a project; authenticity in their presentations; language skills improvement; time management and social interaction through teamwork, collaboration, and community (Assaf, 2018; Miller et al., 2012). In her study investigating the Syrian educational context during times of crisis, Assaf (2018) found that Syrian students' engagement in project-based learning through video making had positive effects on their motivation and attitudes towards English courses. The author also reports how students' writing of video scripts has improved their linguistic skills in addition to developing their oral presentation skills, teamwork, and their organization and planning skills. Several other studies in EFL contexts reported similar benefits (Suhroh et al., 2020; Shaalan, 2020; Sirisrimangkorn, 2018).

Studies on content area classes at the university level report several benefits for the use of PBL, such as the development of cross-curricular competencies including autonomy, teamwork, problem solving and critical thinking (Pacheco et al., 2018), as well as student interaction and collaboration (El-Maaddawy et al., 2018; Gao \& Avis, 2019; Huysken et al., 2018; Rooij, 2009). In the neighbouring Qatari higher education context, Khandakar et al. (2020) report on a case study where they employed a multi-course project-based learning (MPL) approach in two electrical engineering interdisciplinary undergraduate courses at Qatar University and investigated its impact on Education for Sustainable Development. Students participating in the study worked on a design project used to assess if they fulfilled the learning outcomes which focussed on engineering soft skills and project management skills including the ability to communicate effectively, to work collaboratively in a team, to think both critically and creatively, and to manage projects efficiently with realistic constraints and standards. Similar results were also reported in other disciplines such as geosciences and biology (Huysken, Olivey, McElmurry, Gao and Avis, 2019), economics (Pacheco, Guerra, Aguado and McGarry, 2018), social studies (Ciftsi, 
2015), medical education (Kim, 2020), and business (Huang \& Lin, 2017). The benefits of adopting PBL has also surpassed learners to instructors. Wyatt and Nunn (2019) describe how the adoption of a holistic project-based learning at an engineering university in the United Arab Emirates helped develop and sustain a community of practice among faculty members and how it helped develop "collective pedagogy" (p.16) within the community of practice, with synergy between instructors' cognitions and actual practices.

In the field of pre-service teacher preparation programs, Richards and Ressler (2016) report on the experience of a Physical Education curriculum course that integrated the principles of PBL into a curriculum-design project. The project, which hosted 15 PE pre-service students aimed to foster learning authenticity by situating the process of curriculum planning within real school contexts.

Lorraine (1999) believes that PBL should be an integral part of teacher preparation programs. Basing it on brain-based theory, Lorraine (1999) proposes the integration of PBL in early childhood teacher preparation programs and gives examples of various ideas such as "Inclusion in the Early Childhood Classroom", "Designing Outdoor Nature Playgrounds for Early Childhood Programs," and "Incorporating Drama in the Early Childhood Classroom." According to Lorraine (1999), the use of PBL provides educational professionals with mechanisms to help teacher trainees achieve multiple goals in preparation focusing on the knowledge, skills, dispositions, and feelings that are necessary for successful interaction with young children, families, and other professionals inside and outside the classroom. In the South-African teacher education context, Du Toit (2017) reports on a qualitative case study where a Consumer Studies teacherpreparation module was restructured to utilise project-based learning as a primary teaching/learning strategy. Sudents of the module enjoyed PBL and found it beneficial for their personal development and their future careers as teachers.

In a teacher preparation program in a Saudi University, Alrajeh (2020) used a mixed-method approach to investigate the extent that faculty members in teacher preparation programs value and use PBL approaches in their teacher-preparation programs. The research showed that all faculty participating in the study indicated the likelihood to use PBL in teaching practices and confirmed PBL implementation through various forms: activity, problem solving, and doing a project. However, restrictions of the syllabus, financial burdens, and lack of time were highlighted as dilemmas that limit PBL implementation.

In the Omani educational context, there are very few studies that investigated the application of PBL in higher education institutions (Belwal et al., 2020; Dauletova, 2014) and as far as the researchers are aware, there have been no studies investigating the use of PBL in teacher-preparation programs. This study fills this gap. 


\section{The Context of the Study}

This study was conducted at the College of Education of Sultan Qaboos University (SQU) in the Sultanate of Oman. It involved 146 undergraduate and teacherqualification diploma students enrolled in an English language teacher-education program. We investigated students' perceptions towards the use of project-based approach to teaching course design principles as part of a course entitled Educational Curriculum offered to undergraduate students.

The course is normally taken during the third year of the four-year program. It is an introductory course in ELT curriculum design. It covers the basic theories, principles, and approaches in this discipline. It also covers the different stages of the process of curriculum design, such as needs analysis, formulation of goals and objectives, specification and sequencing of content, and methods of evaluation. Furthermore, the course helps students develop the professional skills required for designing, developing, evaluating, and innovating language curricula. It also provides them with a variety of practical techniques for analysing and evaluating the English textbooks used in the Omani schools in order to see how far the covered theoretical framework achieves the general and national purposes of teaching the language.

The course instructors observed that the students had difficulty understanding the theories and principles underpinning curriculum design and development. Further, many students could not see the significance of some of the course design stages. Many students pointed this out in their feedback on the course. Therefore, the researchers decided to adopt the PBL approach to facilitate learning. The course was restructured to integrate PBL in a way that involved students in various tasks and activities that deepened their understanding of the issues related to curriculum development. Students are assessed formatively and summatively. The former includes quizzes, reflections, presentations, and textbook analysis. Summative assessments include a midterm exam and a final exam. Students also have to work on a course design project that is worth $20 \%$ of the course marks. They work in groups of three (but occasionally four) to develop a mini course design. The course design should be based on a real-life issue or need. The students go through all the main stages of course design. The project is an opportunity for the students to apply the course design skills they acquired in the course. The project is assessed based on a presentation and a portfolio using a rubric.

Over the last few iterations of the course, the students presented very creative project designs. Through this PBL approach, the students go through almost all stages of course development starting from needs analysis to assessment and reflection. The only missing component is teaching, because of logistical constraints. Through this project-based course design approach, students get the opportunity to experience the various stages of course design, starting from determining the need or problem to needs analysis and goals and objectives and material development and ending with implementation and reflection. Depending on their topic, they also have the chance to interact with the members of the community. Figure 1 shows a flowchart of the project. There are two main parts, the process and the product. The process part shows the course design 
phases students go through, starting from needs analysis to assessment. The product part displays what the students produce throughout the process. On both sides of the chart there are two types of support, instructor support and peer support. Instructor support is in the form of in-class lectures on course design, and the feedback provided throughout the different stages of the project. The course is divided in a way that reflects the different stages of course design. For each stage, the students are given the theoretical knowledge and skills with a lot of examples and practice. There are deadlines for submitting completed work for different sections of the projects for feedback from the instructor.

As for peer support, after each major stage of course design process, teams are requested to give a briefing to other teams in class (each member of a team joins another team to brief them). This allows for sharing of information and improvement based on constructive feedback between the teams. There are a few occasions when teams have to pilot their instruments/materials. In the absence of a real audience, teams pilot each other's tools and activities with their classmates. This has been shown to be interesting and constructive. Once the teams have completed their course designs, they present their work to the entire class and receive feedback from the instructor and their peers before the final submission to at the end of the semester.

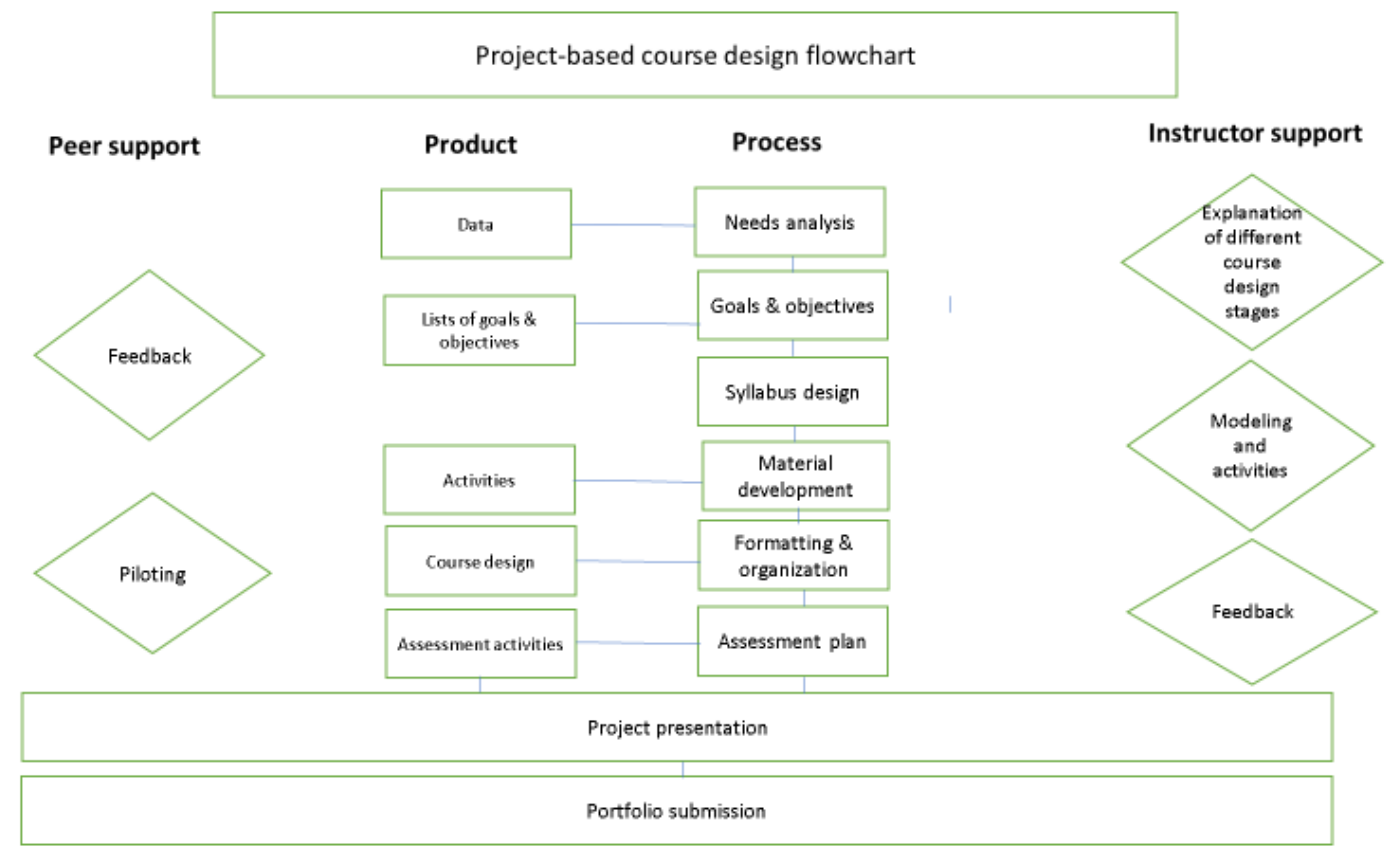

Figure 1: Project-based course design flowchart

The products that the students produce are truly intriguing and meaningful. They are based on real life problems. Some of the these include the following: English for Omani taxi drivers, English for housemaids, English language for mothers of elementary students (1-4), an English course for Sultan Qaboos University graduates of library sciences, and English for patients. 


\section{Methodology}

\subsection{Participants}

The participants were all English major students taking Educational Curriculum course as part of the requirements of their teacher education degree plan and doing the project-based course design as a requirement in the course. The students were in intact classes in the fall semester of two academic years 2018-2019 and 2019-2020. The total number of students was 146. Ninety-three percent of the students were females and $7 \%$ were males.

\subsection{Instrument}

The study employed a questionnaire that solicited students' perceptions about the project-based course. The questionnaire was developed based partly on the course design stages where the students had to build their courses, and partly based on the type of skills that PBL promotes, based on the literature. The questionnaire was validated by a group of experts who suggested a few minor changes. The suggested changes were incorporated into the final version of the questionnaire.

The questionnaire consisted of four sections. The first section was on demographic information. The second section was concerned with students' perceptions towards the course. It contained 12 statements that asked about different aspects of the course. The students rated these statements on a five-point agreement Likert scale ranging from (5) strongly agree to (1) strongly disagree. The third section included nine statements about the degree of difficulty students encountered in undertaking the project. The difficulties mirrored the different stages of the project. The purpose of this section was to ascertain the phases that were the most challenging for the students. The students were asked to rate these statements on a five-point Likert scale ranging from (5) very difficult to (1) not difficult at all. The fourth section consisted of three open-ended questions that asked about the aspects of the PBL course design the students liked the most, the aspects they found the most challenging, and suggestions for improvement.

\subsection{Data analysis}

The demographic data in the first section of the questionnaire was analyzed using frequencies, while the data in sections two and three were analyzed based on means and standard deviation. As for the qualitative data from the open-ended questions in Section Four of the questionnaire, the researchers analyzed the data based on three main issues the questions targeted, namely: the aspects of the course design project the students liked the most, the aspects they found the most challenging and suggestions for improvement. The researchers looked for the highest emerging topics in the data. These were put into broad categories and then examples were provided.

\section{Results}

Ninety-three percent of the participants were females. About half of the students were in their third year, and a little over one third in their fourth year while the rest was in their first year, with a very small percentage in their fifth year. The questionnaire was administered in the fall semester which is semester seven during which the ELT Curriculum course is offered according to the degree plan. Students could be in their third or fourth year depending on their placement in 
the foundation program at entry. Those who score low in the foundation program placement testing spend one or two semesters studying foundational non-credit English, mathematics, and educational technology courses before joining the college. In terms of the degree level, more than two thirds (74\%) of the students were enrolled in the bachelor's degree program and the rest $(26 \%)$ in the teacherpreparation diploma. The university admits about 80 students into the bachelor (English major) program and about 20 students into the one-year long teacherqualification diploma program every year.

\subsection{Student-teachers' perceptions towards project-based design}

The students had very positive responses to the statements (Table 1 which is a very positive outcome. More than $80 \%$ of the respondents said that they had enjoyed working on the course design project. In addition, more than $90 \%$ of the students "strongly agreed" or "agreed" with the statement: "Overall, I have learnt a lot from this project." The other statements also attracted a very positive response. For example, more than $90 \%$ of the students agreed that the course design project helped them understand the different components of course design. Similarly, the majority of the students (91\%) agreed that the course design project helped them understand the link between the different components of course design. This was one of the key objectives of the course, which is to link theory to practice. The percentage of the students who "strongly disagreed" or "disagreed" with the statements did not exceed $6.1 \%$ in all the fourteen statements; it ranged from $0.7 \%$ to $6.1 \%$.

Moreover, there were a few statements with neutral responses. One of these statements was the one that read "The project helped me understand the potential challenges of course design in the Omani educational context." Even though more than $80 \%$ of the students agreed, $17.4 \%$ did not seem to be sure this was achieved. There were also a few other statements where the students had doubts. These are related to skill development, namely report writing skills, problem solving skills, critical thinking, teamwork skills, time management. The percentages of the neutral responses ranged from $11 \%$ in the statement about critical thinking skills to $19 \%$ regarding time management skills.

Table 1: Student-teachers' perceptions towards the course

\begin{tabular}{|c|c|c|c|c|c|c|c|c|}
\hline Statements & $\mathbf{N}$ & $\mathbf{M}$ & SD & 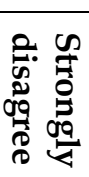 & 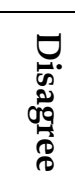 & $\begin{array}{l}Z \\
\Xi \\
\Xi \\
\Xi \\
\Xi\end{array}$ & $\begin{array}{c}\vec{D} \\
\text { do } \\
\mathbb{D} \\
0\end{array}$ & 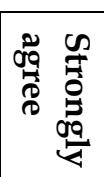 \\
\hline $\begin{array}{l}\text { 1. I enjoyed working on the } \\
\text { course design project. }\end{array}$ & 142 & 4.04 & .862 & 2.8 & .7 & 16.2 & 50.7 & 29.6 \\
\hline $\begin{array}{l}\text { 2. The course design } \\
\text { project helped me } \\
\text { achieve the outcomes of } \\
\text { the course. }\end{array}$ & 138 & 4.27 & .769 & 1.4 & .7 & 8.7 & 47.8 & 41.3 \\
\hline $\begin{array}{l}\text { 3. The course design } \\
\text { project helped me } \\
\text { understand the different } \\
\text { components of course } \\
\text { design. }\end{array}$ & 144 & 4.51 & .669 & .7 & 0.0 & 5.6 & 35.4 & 58.3 \\
\hline
\end{tabular}




\begin{tabular}{|c|c|c|c|c|c|c|c|c|}
\hline $\begin{array}{l}\text { 4. The course design } \\
\text { project helped me } \\
\text { understand the link } \\
\text { between the different } \\
\text { components of course } \\
\text { design. }\end{array}$ & 143 & 4.38 & .690 & 1.4 & 0.0 & 7.7 & 42.7 & 48.3 \\
\hline $\begin{array}{l}\text { 5. The project helped me } \\
\text { understand the potential } \\
\text { challenges of course } \\
\text { design in the Omani } \\
\text { educational context. }\end{array}$ & 144 & 4.15 & .722 & 0.0 & .7 & 17.4 & 47.9 & 34.0 \\
\hline $\begin{array}{l}\text { 6. The project helped me } \\
\text { develop my critical } \\
\text { thinking skills. }\end{array}$ & 143 & 4.16 & .635 & 0.0 & .7 & 11.2 & 59.4 & 28.7 \\
\hline $\begin{array}{l}\text { 7. The project helped me } \\
\text { develop my problem- } \\
\text { solving skills. }\end{array}$ & 144 & 4.10 & .683 & 0.0 & 2.1 & 12.5 & 59.0 & 26.4 \\
\hline $\begin{array}{l}\text { 8. The project helped me } \\
\text { develop my report } \\
\text { writing skills. }\end{array}$ & 143 & 4.06 & .743 & 0.0 & 2.8 & 16.1 & 53.1 & 28.0 \\
\hline $\begin{array}{l}\text { 9. The project helped me } \\
\text { develop my teamwork } \\
\text { skills. }\end{array}$ & 141 & 4.18 & .973 & 2.8 & 3.5 & 12.1 & 36.2 & 45.4 \\
\hline $\begin{array}{l}\text { 10. The project helped me } \\
\text { develop my time } \\
\text { management skills. }\end{array}$ & 141 & 4.10 & .777 & .7 & .7 & 19.1 & 46.8 & 32.6 \\
\hline $\begin{array}{l}\text { 11. The scoring rubric } \\
\text { guided me throughout } \\
\text { the different stages of the } \\
\text { project. }\end{array}$ & 142 & 4.08 & .859 & .7 & 3.5 & 18.3 & 42.3 & 35.2 \\
\hline $\begin{array}{l}\text { 12. Overall, I have learnt a } \\
\text { lot from this project. }\end{array}$ & 144 & 4.38 & .793 & 1.4 & 1.4 & 6.9 & 38.2 & 52.1 \\
\hline
\end{tabular}

\subsection{Difficulties that students faced}

The second research question was about the difficulties students encountered during the project. The means of the students' responses to the nine statements ranged from 2.41 (dividing the work among the team members) to 3.26 (finding participants for the needs analysis). The challenge in finding participants for the needs analysis is understandable as many of the projects involved participants from outside campus and as the majority of the students were females (92\%) residing on campus they are bound to were unable to travel because certain transportation or social restrictions. With regards to the other statements, as Table 2 shows, overall, the students did not encounter serious problems during the project. However, a closer look at the results, we noticed that many of the responses were between 'not difficult' and 'not sure'. This prompted us to look for another way to analyze the data. We decided to use frequencies to check for the distribution of responses. We noticed that in all the statements, there was at least $20 \%$ of the students who marked the statements as 'difficult' or 'very difficult'. This means that although, on average, the students managed the 
various stages of the project, there was a subset of the sample who encountered some difficulties at certain stages of the process.

Table 2: Students' perceptions of the level of difficulty of different components of the project-based course-design

\begin{tabular}{|c|c|c|c|c|c|c|c|c|}
\hline \multicolumn{9}{|c|}{ Frequencies in percentages } \\
\hline Statements & $\mathbf{N}$ & 当 & to & 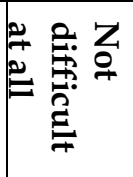 & 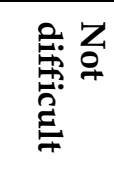 & \begin{tabular}{l}
$Z$ \\
\multicolumn{1}{c}{} \\
0 \\
$\infty$ \\
$\vdots$ \\
0
\end{tabular} & 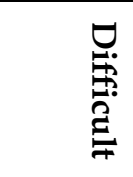 & 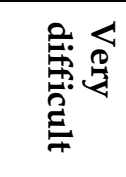 \\
\hline $\begin{array}{l}\text { Finding a topic for } \\
\text { the project }\end{array}$ & 138 & 2.63 & 1.184 & 17.4 & 38.4 & 12.3 & 27.5 & 4.3 \\
\hline $\begin{array}{l}\text { Dividing the work } \\
\text { among the team } \\
\text { members. }\end{array}$ & 136 & 2.41 & 1.250 & 24.3 & 41.2 & 14.0 & 10.3 & 10.3 \\
\hline $\begin{array}{l}\text { Finding } \\
\text { participants for the } \\
\text { needs analysis }\end{array}$ & 136 & 3.26 & 1.301 & 11.0 & 23.5 & 11.0 & 36.8 & 17.6 \\
\hline $\begin{array}{l}\text { Designing suitable } \\
\text { instruments for } \\
\text { needs analysis. }\end{array}$ & 138 & 2.93 & .991 & 5.1 & 34.1 & 26.1 & 31.9 & 2.9 \\
\hline $\begin{array}{l}\text { Using the results } \\
\text { from the needs } \\
\text { analysis to plan } \\
\text { the course. }\end{array}$ & 137 & 2.61 & 1.059 & 10.9 & 46.7 & 15.3 & 24.1 & 2.9 \\
\hline $\begin{array}{l}\text { Writing the goals } \\
\text { and objectives. }\end{array}$ & 139 & 2.77 & 1.131 & 10.1 & 39.6 & 21.6 & 20.9 & 7.9 \\
\hline $\begin{array}{l}\text { Designing a } \\
\text { sample } \\
\text { unit/activity. }\end{array}$ & 136 & 2.81 & 1.079 & 9.6 & 36.0 & 22.8 & 27.2 & 4.4 \\
\hline $\begin{array}{l}\text { Deciding about the } \\
\text { appropriate } \\
\text { assessments. }\end{array}$ & 136 & 2.82 & 1.013 & 6.6 & 39.0 & 23.5 & 27.9 & 2.9 \\
\hline $\begin{array}{l}\text { The final writing } \\
\text { of the project. }\end{array}$ & 139 & 2.73 & .997 & 7.9 & 39.6 & 26.6 & 23.0 & 2.9 \\
\hline
\end{tabular}

\subsection{The most liked aspects of the course}

Based on students' responses to the first open-ended question, there were four main aspects of the course that the students favoured. The first one was about the experience as a whole. As one student has said: "The freedom, the project was not restricting at all so it allowed a space for creativity." Also, another student commented: "This is one of the few projects that I felt like I was applying the information I learned from the course. I appreciate that." This shows that the students were engaged in the process and found it beneficial and meaningful. The fact that the project had a beginning and an end has given the students a sense of achievement. One student described what she liked the most: "Gathering all the information and seeing the final product." Another related answer was about the sequential nature of the project, where she said: "Doing the project step by step which is very helpful." The students felt that the idea of creating a course was 
beneficial to them as "it enables students of getting first-hand experience of course designing."

One of the more specific aspects the students liked was the needs analysis stage. Needs analysis involves creating an instrument, collecting data and analyzing results. Though challenging, needs analysis can be an interesting personal task, as students develop their own data collection instruments for a problem of their own choice. They collect data and try to make sense of what the respondents have stated so that they can make meaningful decisions for their own course. At this stage of their degree, this might be the first time that the students get the opportunity to collect data and analyze it. So, the students may feel enthusiastic about the process. As one student has said, "Distributing the questionnaires online and receiving the results because I was curious about them." Other students mentioned specific data collection instruments, namely "distributing the questionnaire" and "conducting interviews." This quote summarizes the students' opinion towards needs analysis: "Needs analysis as I met new people and I had new experiences, everything was real and practical. I enjoyed meeting and interviews." Another student added: "Need analysis because it allows us to interact with target people and listening to their need and how they are enthusiastic to learn English."

Another aspect the students found equally beneficial was designing materials. The students were given the choice of adopting/recommending materials from a commercial textbook or designing their own. It was interesting to see that many of the students chose to develop their own activities. The students liked the task of "Searching about the suitable activities for the topic that suit the goals and objectives." This in fact shows a high level of understanding of the course design requirements. That is to say, students were taught to use the goals and objectives as the basis for material development. It seems they understood this essential requirement and implemented it. Some students liked "Collecting the activities from books" and "Deciding on the best materials to be used", while others enjoyed "The construction of activities."

The third aspect related to course design was assessment. In this course, the students were required to propose a simple assessment plan for their course. The plan should include formative and summative assessments. It seems that the students appreciated this aspect of the project. As one student has described it: "...it [the assessment part] makes me feel like a real teacher."

In addition to foregoing aspects related to the different stages of course development, the students liked the fact that the course helped them improve their academic and professional skills. One student commented: "When we were collecting the data for need analysis because it allows us to contact different types of people and develop our interviewing skills." Another student also said: "Doing the project since it improves many aspects such as managing time, work in groups, team working." 


\subsection{The most challenging aspects}

The students were asked to list the most challenging aspects of the course. They mentioned several challenges. One of these was needs analysis. It is true that needs analysis was listed earlier as one of the positive aspects. Many students enjoyed the construction of data gathering tools. However, the stages that followed the construction of the tools were found to be demanding. This includes finding and interacting with participants, as one student has put it: "Finding participants for the needs analysis was very difficult/ challenging." Another student said: "Dealing with people who are busy and people who know nor Arabic neither English." Other students mentioned the manipulation and processing of data from the needs analysis. They faced difficulty in analysing the data from needs analysis, deriving the goals and objectives from the data, matching the needs analysis with the course objectives and materials, planning the course from needs analysis, analysing the questionnaire because not all questions were answered, and analysing the results.

Another student added that: "Interpreting the results of needs analysis was challenging because according to the results the target group needed all the skills and we had to focus on all of them." This is about filtering the data and deciding on the most relevant and important aspects based on learners' needs, resources, and constraints.

The second aspect the students found demanding was writing goals and objectives. This issue was also among the ones that about two thirds of the students rated as being difficult or very difficult in the previous section. In this course, the students are trained in how to write goals and objectives. However, we have noticed during the course that this is one of the hardest things to learn. For example, they had trouble distinguishing between goal and objective statements, writing measurable statements, choosing the right action verb, and limiting the objective statement to one action.

The third challenge the students cited was related to the selection of the syllabus type. In this course, the students are taught different syllabus types, such as grammatical syllabus, lexical syllabus, task-based syllabus, thematic syllabus, functional syllabus, and skills-based syllabus. The students were also familiarized with the idea of layered and integrated syllabuses, and the difference between product-based versus process-based syllabus types. Deciding about a suitable syllabus requires that the course designer is fully familiar with the syllabus type, the learners' needs and goals and objectives, among other things. The students faced difficulty in two main aspects, choosing the right syllabus type and writing the content of the course syllabus.

There were other areas related to project management, such as time management, and working in groups. As mentioned earlier in the section on students' perceptions, these are among the statements that some students had doubts about. The students listed the following challenges: working in groups of four, working with a partner on the project, managing time, and managing time with all assignments they must do in other courses. 
However, some students have learned to cope with the time pressure, as shown in this statement by one student in response to the question: "Managing time to meet with each other since we have exams and many lectures at the day so we met at night." At the beginning of the semester, the students were asked to create a work plan with deadlines. Many of them were hesitant to do that because they were not used to that in their lives or in other courses. There was no time to check individual work plans but the students were constantly reminded of adhering to their plans.

\subsection{Suggestions for improvement}

The last question asked students for suggestions for improvement. The students offered many useful suggestions. The first suggestion was to provide a model for the final project. One student wrote: "Give more authentic samples during the lessons before doing the project to familiarize students with what they are doing". Another student suggested: "Include an example of an 'A' student paper, so we can use it as a model." The second suggestion was about managing teamwork. One student stated that: "It is better to check from time to time all members of the group are working the project because some of them rely on other members and do nothing." Another student suggested: "To either make the project individual or the instructor should divide the parts of the design process among the group members because some of them are not working and they were all depending on one member only." The third suggestion was about providing more guidance. Students suggested that the teachers should monitor students' work more regularly and provide more guidance and directions. The final suggestion was concerned with the submission procedure. The students suggested they are asked to finish each part in a certain time then submit it to the instructor so that the work will be more organized and completed on time.

As can be gleaned from the students' suggestions, they are asking for more guidance and more structured support. While this could be provided and could be helpful for some students, it might be too limiting for others. The project constitutes a rather big chunk of the total marks of the course $(20 \%)$ and so the students are concerned about the marks they earn but nevertheless the amount of guidance is an area worth exploring further. This is an issue that is not yet fully researched in the literature on project-based learning. The students are given a 'flexible' template for the final product and they are shown a few examples of completed projects from previous semesters. However, it seems students expect more guidance.

\section{Discussion}

The study revealed that students showed very positive responses towards the use of PBL. Students' positive responses towards the use of PBL in their course design project is supported by several other studies in the literature (Baghoussi and El Ouchdi, 2019; Bell, 2010; Hafner \& Fun, 2012; Meyer \& Wurdinger, 2016; Miller et al., 2012), which show that students overall prefer PBL over more traditional approaches to learning. For example, Gies (2017) found that students were motivated to learn via PBL, as they perceived it as an engaging strategy that develops problem solving and critical thinking skills. Students also reported that PBL helps connect them to their college study, and future job and helps them 
develop more positive attitudes towards course content. Students in the present study also reported the benefits of PBL in helping them understand the main concepts of the course and the connection between them, hence meeting its objectives (Assaf, 2018; Miller et al., 2012; Pacheco et al., 2018).

Furthermore, students reported their appreciation of the practical aspect of the course which allows them to come closer to the Omani community, hence constructing a new understanding of the course through interaction with the environment (Demian, 2007; Dolmans et al., 2005; Panasan \& Nuangchalerm, 2010). This is especially important in the course Educational Curriculum where students are taught the importance of considering both micro and macro contexts and constraints before, during and after course design.

The findings of the study also revealed that the students encountered several challenges while working in their projects, such as conducting needs analysis and writing goals and objectives. Grant (2002) explains that the implementation of PBL could be a challenging and an overwhelming experience for students who are not familiar with its processes. The adoption of PBL changes both the general atmosphere and the nature of learning in the class, which consequently transforms the roles of both the teacher and students (Baghoussi \& El Ouchdi, 2019; Bell, 2010; Dolmans et al., 2005). In PBL, students are expected to be more independent. In this study, the students enjoyed the process of needs analysis, yet the authenticity of the task presented challenges such as difficulties in getting an adequate number of participants, delays in getting responses and data analysis. These are all authentic challenges. As for the writing of goals and objectives, it is well known that writing specific, measurable, attainable, relevant and time-bound (what is known as SMART objectives) is not easy (Anderson et al., 2001). The ability to produce such specific outcome statements comes with experience (Graves, 2000). In addition, some students may not have had the time to contemplate on the data they had gathered, or simply they did not have enough knowledge about the needs of the target clients. In a normal situation, the course designer would have more time to gather information using multiple sources.

Based on their experiences, students made a number of suggestions for future revision and implementation of the course; one mainly focusing on the kind of support they felt necessary for the project, be it in the form of more guided instruction or in the provision of good models and examples of the project as a final product. The result aligns with those of Johnson and Cuevas (2016) who found that the autonomy provided to students in a PBL class could sometimes be counterproductive if there is no adequate monitoring from the teacher and suggest that students are provided with explicit instruction prior to engagement in inquiry PBL to make their experience valid. Teachers can design projects that meet the objectives if they start slowly and move gradually from a step to another (Zhang et al., 2009). Students also needed support in teamwork.

Although PBL, by nature emphasizes the principles of cooperative learning, some students may not have experienced group work and peer interaction, or do not know the principles of effective and productive group work. As a result, the 
teacher might be expected to teach students to work collaboratively, avoid conflicts, and share resources (Grant, 2002).

The findings revealed by this study support what has been reported in the literature in terms of the benefits obtained by students through the adoption of and engagement with PBL (Pacheco et al., 2018; Assaf, 2018; Miller et al., 2012). It particularly adds to the literature in teacher preparation programs in general, and the Omani context in particular, especially that no previous studies investigated the use of PBL in the Omani teacher preparation setting. In spite of the challenges faced by students, which we argue are adding to the authenticity of the experience, the advantages gained by them show that PBL can work effectively in achieving the outcomes of teacher preparation programs. In the case of Educational Curriculum at Sultan Qaboos University, the results showed that PBL can provide a realistic framework for students to contextualize curricular-related decisions and engage in practical application of the course's content.

\section{Conclusion and Limitations}

Project-based learning can be a powerful instructional method in teacher education programs. In this study, the aim of applying the project-based approach was to help the Omani teacher trainees understand course design. We believe that the best way for students to grasp concepts is by experience. This is what projectbased learning provides. Based on the findings of this study, it is clear that the students have found the approach effective. The approach helped students understand what would otherwise be abstract to them. The knowledge and skills the students have learned in this course will hopefully be beneficial for them when joining the teaching force. There were some challenges that have to be addressed in the future iterations of the course. The students have offered some useful suggestions for improvement. It is clear that students need more guidance in some phases of the project.

As with any research, it is important to highlight the limitations of the study. First, this study was essentially a self-report study and therefore its findings and conclusions are more relevant to the context of the study and may not be applicable to other contexts. Second, the questionnaire contained statements that tackled many concepts and skills some of which need to be objectively measured such as critical thinking and problem solving. Therefore, it would be good in future to assess acquisition of such content knowledge and skills using standardized tests or scales. Another way to study the effect of PBL is through an experimental research design where a control group of students receive some traditional instruction (with no PBL being used) and a group incorporating PBL methods and then compare results.

\section{References}

Alrajeh, T. S. (2020). University Faculty Members Perceptions Regarding the Level of the Value and Use of Project-Based Learning in Teacher Preparation Programs: A Mixed Methods Study (Order No. 28149836). ProQuest Dissertations \& Theses Global. 
Anderson, L., Krathwohl, D., Airasian, P., Cruikshank, K., Mayer, R., Pintrich, P., Raths, J., \& Wittrock, M. (2001). A taxonomy for learning, teaching, and assessing: A revision of Bloom's taxonomy of educational objectives. New York: Longman.

Assaf, D. (2018). Motivating Language Learners during Times of Crisis through Projectbased Learning: Filming Activities at the Arab International University (AIU). Theory and Practice in Language Studies, 8(12), 1649-1657. http://dx.doi.org/10.17507/tpls.0812.10

Baghoussi, M., \& El Ouchdi, I. Z. (2019). The Implementation of the Project-Based Learning Approach in the Algerian EFL Context: Curriculum Designers' Expectations and Teachers' Obstacles. Arab World English Journal, 10(1), 271-282. https://dx.doi.org/10.24093/awej/vol10no1.23

Baran, M., \& Maskan, A. (2010). The effect of project-based learning on pre-service physics teachers' electrostatic achievements. Cypriot Journal of Educational Sciences, 5, 243 257.

Bell, S. (2010) Project-Based Learning for the 21st Century: Skills for the Future, The Clearing House. https://doi.org/10.1080/00098650903505415

Belwal, R., Belwal, S., Sufian, A. B., \& Al Badi, A. (2020), "Project-based learning (PBL): outcomes of students' engagement in an external consultancy project in Oman". Education + Training, 63(3), 336-359. https://doi.org/10.1108/ET-01-2020-0006

Boss, S., \& Krauss, J. (2007). Reinventing project-based learning: Your field guide to real-world projects in the digital age. Washington DC: International Society for Technology in Education.

Burlbaw, L., Ortwein, M., \& Williams, J. (2013). The Project method in historical context. In STEM project-based learning: An integrated science, technology, engineering, and mathematics (STEM) approach (2nd ed., pp. 7-14). Rotterdam: Sense Publishers.

Ciftci, S. (2015). The Effects of Using Project-Based Learning in Social Studies Education to Students' Attitudes towards Social Studies Courses. Procedia - Social and Behavioral Sciences, 186, 1019-1024.

Dauletova, V. (2014). Expanding Omani Learners' Horizons Through Project-Based Learning: A Case Study. Business Communication Quarterly, 77(2), 183203. https://doi.org/10.1177/2329490614530553

Demian, P. (2007). Theory and practice of project-based learning in built environment education: A CEBE case study on innovative design project work. A case study by the Centre for Education in the Built Environment, 1-9.

Dolmans, D., De Grave, W., Wolfhagen, I., \& Vleuten, C. (2005). Problem-based learning: future challenges for educational practice and research. Medical Education, 39, 732741. https://doi.org/10.1111/j.1365-2929.2005.02205.x

Doppelt, Y. (2005). Assessment of Project-Based Learning in a MECHATRONICS Context. Journal of Technology Education, 16(2) 7-24. https://doi.org/10.21061/jte.v16i2.a.1

Du Toit, A. (2017). A framework for project-based learning in consumer studies teacher preparation. International Journal of Home Economics, 10(2), 171-179.

El-Maaddawy, T., El-Hassan, H., \& Al Jassmi, H. (2018). Student perceptions of the use of project-based learning in civil engineering courses. In 2018 IEEE Global Engineering Education Conference (EDUCON) (pp. 243-250). Santa Cruz de Tenerife: IEEE.

Eskrootchi, R., \& Oskrochi, G. R. (2010). A study of the efficacy of project-based learning integrated with computer-based simulation - STELLA. Educational Technology $\mathcal{E}$ Society, 13(1), 236-245.

Gies, S. (2017). Project-based learning: Stakeholders' perceptions and student achievement impact (Ph.D. Thesis). Ball State University. 
Goldstein, O. (2016). A project-based learning approach to teaching physics for pre-service elementary school teacher education students. Cogent Education, 3(1), 1-12. https://doi.org/10.1080/2331186X.2016.1200833

Grant, M. (2002). Getting A grip on project-based learning: Theory, cases and recommendations. Meridian: A Middle School Computer Technologies Journal, 5(1), 17. http://www.ncsu.edu/meridian/win2002/514

Graves, K. (2000). Designing language courses: A guide for teachers. Boston: Heinle and Heinle.

Habók, A., \& Nagy, J. (2016). In-service teachers' perceptions of project-based learning. SpringerPlus, 5(83), 1-14. https://doi.org/10.1186/s40064-016-1725-4

Harmer, N., \& Stokes, A. (2018). "Choice may not necessarily be a good thing": student attitudes to autonomy in interdisciplinary project-based learning in GEES disciplines. Journal of Geography in Higher Education, 40(4), 531-545. http://dx.doi.org/10.1080/03098265.2016.1174817

Holm, M. (2011). Project-based instruction: A review of the literature on effectiveness in prekindergarten through 12th grade classrooms. InSight: Rivier Academic Journal, 7(2), 1-13.

Holst, J. K. (2003). Implementing project-based learning in pre-service teacher education. (A Report). Higher Education Research and Development Society of Australasia. https:// citeseerx.ist.psu.edu/viewdoc/download?doi=10.1.1.111.5998\&rep=rep $1 \&$ type $=$ pdf

Holubova, R. (2008). Effective teaching methods: Project-based learning in physics. USChina Education Review, 27-36. https://files.eric.ed.gov/fulltext/ED504949.pdf

Howard, J. (2002). Technology-enhanced project-based learning in teacher education: Addressing the goals of transfer. Journal of Technology and Teacher Education, 10(3), 343-364. https://www.learntechlib.org/primary/p/15139/

Huysken, K., Olivey, H., McElmurry, K., Gao, M., \& Avis, P. (2019). Assessing collaborative, project-based learning models in introductory science courses. Journal of the Scholarship of Teaching and Learning, 19(1), 6-28. https://doi.org/10.14434/josotl.v19i1.26777

Huang, C., \& Lin. C. (2017). Flipping Business Education: Transformative Use of TeamBased Learning in Human Resource Management Classrooms. Journal of Educational Technology \& Society, 20(1), 323-336. http://www.jstor.org/stable/jeductechsoci.20.1.323

Johnson, S., \& Cuevas, J. (2016). The effects of inquiry project-based learning on student reading motivation and student perceptions of inquiry learning processes. Georgia Educational Researcher, 13(1), 51-85. https://doi.org/10.20429/ger.2016.130102

Jollands, M., Jolly, L., \& Molyneaux, T. (2012). Project-based learning as a contributing factor to graduates' work readiness. European Journal of Engineering Education, 37(2), 143-154. https://doi.org/10.1080/03043797.2012.665848

Khandakar, A., Chowdhury, M., Gonzales, A., Touati, F., Emadi, N., \& Ayari, M. (2020). Case Study to Analyze the Impact of Multi-Course Project-Based Learning Approach on Education for Sustainable Development. Sustainability, 12(2), 480. http://dx.doi.org/10.3390/su12020480

Kim, K. (2020). Project-based learning approach to increase medical student empathy. Medical Education Online, 25:1. http://dx.doi.org/10.1080/10872981.2020.1742965

Lorraine, D. (1999). Learning through projects in early childhood teacher education. Journal of Early Childhood Teacher Education, 20 (3), 317326. http://dx.doi.org/10.1080/0163638990200309 
Marra, R., Jonassen, D. H., Palmer, B., \& Luft, S. (2014). Why problem-based learning works: Theoretical foundations. Journal on Excellence in College Teaching, 25(3\&4), 221-238.

Meyer, K., \& Wurdinger, S. (2016). Students' perceptions of life skill development in project-based learning schools. Journal of Educational Issues, 2(1), 91-114.

Miller, L., Hafner, C. A., \& Fun, C. (2012). Project-based learning in a technologically enhanced learning environment for second language learners: Students' perceptions. E-Learning and Digital Media, 9(2), 183-195. http://dx.doi.org/10.2304/elea.2012.9.2.183

Mioduser, D., \& Betzer, N. (2007). The contribution of project-based-learning to highachievers' acquisition of technological knowledge and skills. Int J Technol Des Educ, 18, 59-77. https://doi.org/10.1007/s10798-006-9010-4

Nikolaeva, S. (2012). Improving initial teacher education by using the project-based approach. Educational Research, 1(1), 51-60. https://doi.org/10.5838/erej.2012.11.04

Pacheco, M., Guerra, D., Aguado, C., \& McGarry, C. (2018). Cogent Education, 6, 1-17. https:// doi.org/10.1080/2331186X.2019.1616364

Panasan, M., \& Nuangchalerm, P. (2010). Learning outcomes of project-based and inquirybased learning activities. Journal of Social Sciences, 6(2), 252-255. https://doi.org/10.3844/jssp.2010.252.255

Richards, K., \& Ressler, J. (2016). Engaging preservice teachers in context-based, actionoriented curriculum development. Journal of Physical Education, Recreation $\mathcal{E}$ Dance, 87(3), 36-43.

Rooij, S. (2009). Scaffolding project-based learning with the project management body of knowledge (PMBOK). Computers \& Education, 52, 210-219, https://doi.org/10.1016/j.compedu.2008.07.012

Roessingh, H., \& Chambers, W. (2011). Project-based learning and pedagogy in teacher preparation: Staking out the theoretical mid-ground. International Journal of Teaching and Learning in Higher Education, 23(1), 60-71.

Shaalan, I. E.A. (2020). Integrating Project-Based Learning Strategies in the Design of an ESP Dental Vocabulary Course for ESL Malaysian Majors. Arab World English Journal, 11 (3) 464-483. https://dx.doi.org/10.24093/awej/vol11no3.29

Sirisrimangkorn, L. (2018). The use of project-based learning focusing on drama to promote speaking skills of EFL learners. Advances in Language and Literary Studies, 9(6), 14-20. http://dx.doi.org/10.7575/aiac.alls.v.9n.6p.14

Slough, S., \& Milam, J. (2013). Theoretical framework for the design of STEM project-based learning. In STEM Project-based learning: An integrated science, technology, engineering, and mathematics (STEM) approach (2nd ed., pp. 15-27). Rotterdam: Sense Publishers.

Suhroh, F., Cahyono, B., \& Astuti, U. (2020). Effect of Using Whiteboard Animation in Project-Based Learning on Indonesian EFL Students' English Presentation Skills across Creativity Levels. Arab World English Journal (AWEJ). https://ssrn.com/abstract $=3675966$

Susanti, Susilowibowo, J., \& Hardini, H. (2019). Effectiveness of project-based learning models to improve learning outcomes and learning activities of students in innovative learning. International Conference on Economics, Education, Business and Accounting. (pp. 82-95). KnE Social Sciences.

Thomas, J. W. (2000). A review of research on project-based learning. San Rafael, CA: Autodesk Foundation.

Vogler, J., Thompson, P., Davis, D., Mayfield, B., Finley, P., \& Yasseri, D. (2018). The hard work of soft skills: augmenting the project-based learning experience with 
interdisciplinary teamwork. Instructional Science, 46(3), 457-488. https://doi.org/10.1007/s11251-017-9438-9

Wyatt, M., \& Nunn, R. (2019). Tracing the Growth of a Community of Practice Centered on Holistic Project-Based Learning in Communication at an Engineering University in the United Arab Emirates: Insights from a Socially-Situated Teacher Cognition Perspective [42 paragraphs]. Forum: Qualitative Social Research, 20(2), Article 8. http://dx.doi.org/10.17169/fqs-20.2.3170

Zhang, K., Peng, S. W., \& Hung, J. (2009). Online collaborative learning in a project-based learning environment in Taiwan: a case study on undergraduate students' perspectives. Educational Media International, 46(2), 123-135. https://doi.org/10.1080/09523980902933425 